\title{
Does calcined bone meal serve as phosphate for pastures in family farming?
}

\section{Farinha de ossos serve como fosfato para pastos na agricultura familiar?}

\author{
Jhonnatan Wilker de OLIVEIRA'; Ariane EVALD'; Acácio Bezerra de MIRA'; \\ Adjalma Campos de FRANÇA NETO²; Elvno FERREIRA ${ }^{3}$ \\ ${ }^{2}$ Doutor Universidade Federal de Rondônia, Departamento de Agronomia \\ ${ }^{3}$ Autor para correspondência. Dr., Universidade Federal de Rondônia, Departamento de Medicina Veterinária. Av. Norte Sul, \\ 7.300 - Bairro Nova Morada. Rolim de Moura, Rondônia. CEP: 76.940-000. elvino@unir.br
}

${ }^{1}$ Acadêmico de Agronomia, Universidade Federal de Rondônia

\section{Recebido em: 08-08-2017; Aceito em: 18-11-2017}

\begin{abstract}
To support rural extension activities for family farming in the western Amazon, we evaluated the production of Mombasa grass (Panicum maximum Jacq) as a function of phosphorus sources (single superphosphate and calcined bone meal) and rates $\left(100,200\right.$, and $\left.400 \mathrm{~kg} \mathrm{ha}^{-1} \mathrm{P}_{2} \mathrm{O}_{5}\right)$. The experimental design was a randomized complete block, in a $2 \times 3+1$ factorial scheme. The use of calcined bone meal yielded a dry matter $\left(1.73 \mathrm{t} \mathrm{ha}^{-1}\right.$ cutting $\left.^{-1}\right)$ and a plant height $(55 \mathrm{~cm})$ higher than the control $\left(1.03 \mathrm{t} \mathrm{ha}^{-1}\right.$ cutting $^{-1}$ and $35 \mathrm{~cm}$, respectively). However, the values were lower than those obtained with single superphosphate ( $3.19 \mathrm{t} \mathrm{ha}^{-1} \mathrm{DM}$ and $91 \mathrm{~cm}$ in height). Regarding the dry matter production in the experimental period (202 days, five cuttings), the calcined bone meal promoted $54 \%$ of the production obtained with the use of single superphosphate.
\end{abstract}

Additional keywords: Nutrient cycling; Panicum maximum; phosphate solubility.

\begin{abstract}
Resumo
A fim de apoiar ações de extensão rural para agricultura familiar na Amazônia Ocidental, avaliou-se a produção de Mombaça (Panicum maximum Jacq) em função de fontes de fósforo (superfosfato simples e farinha de ossos calcinada) e doses (100; 200 e $400 \mathrm{~kg} \mathrm{ha}^{-1}$ de $\mathrm{P}_{2} \mathrm{O}_{5}$ ), em blocos casualizados, em esquema fatorial $2 \times 3+1$. O uso de farinha de ossos calcinada proporcionou produção de matéria seca $\left(1,73 \mathrm{t} \mathrm{ha}^{-1} \mathrm{corte}^{-1}\right)$ e altura das plantas (55 $\mathrm{cm})$ superiores aos da testemunha $\left(1,03 \mathrm{tha}^{-1} \mathrm{corte}^{-1} \mathrm{e} 35 \mathrm{~cm}\right.$, respectivamente). Contudo, os valores foram inferiores aos obtidos com superfosfato simples $\left(3,19 \mathrm{t} \mathrm{ha}^{-1} \mathrm{MS}\right.$ e $91 \mathrm{~cm}$ de altura). Em relação à produção de massa seca no período experimental (202 dias, cinco cortes), a farinha de ossos calcinada promoveu $54 \%$ da produção obtida com o uso de superfosfato simples.
\end{abstract}

Palavras-chave adicionais: Ciclagem de nutrientes; Panicum maximum; solubilidade de fosfato.

\section{Introduction}

In the Amazon, pasture areas are stablished after slash and burn the forest, since it's a low cost practice of removal the vegetation cover and cleaning the area. However, the initial soil fertility declines gradually, and after 5 or 8 years, the productivity of the system is compromised (Noronha et al., 2010). Factors such as low natural fertility of soils, low $P$ levels, the use of poorly adapted germplasm, and inadequate management practices also reduce the pasture productivity sustainability over 30 million hectares of the Brazilian Legal Amazon, that is, in $50 \%$ of the planted pastures (Townsend et al., 2010; Dias-Filho, 2015). In a general context, soils under pasture are acidic and of low natural fertility. Once degraded, there is interest in opening up new areas. As an alternative to pasture recovery, cereal planting is promoted in order to provide residual effect from the soil correction and fertilization for forage reestablishment and cost reduction (Teixeira et al., 2016).

Among the nutritional deficiencies, phosphorus has been highlighted, especially in the forage establishment (Almeida et al., 2005). Readily soluble $P$ sources increase dry matter production in the first crop year, but this effect does not last until the second year. For less soluble sources, the inverse is verified (leiri et al., 2010). For pasture establishment in the state of Rondônia, Costa (2004) recommends the use of readily soluble sources in the furrow for forage establishment, in addition to broadcasting low solubility sources for forage persistence. However, low solubility sources of phosphate are not available at Rondônia trade. In this sense, the calcined bone meal is a potential $P$ source, since it allows the supply of phosphorus and calcium to the plants (Mattar et al., 2013).

In the state of Rondônia, the solid waste of small meat-processing establishments is mostly destined to landfills or even discarded without proper sanitary control, generating environmental and public health problems. This action represents a nutrient wasting since the bones are constituted basically by hydroxyapatite or biological apatite that, if calcinated, decompose into tricalcium phosphate, calcium oxide, 
and water (Miyahara et al., 2007; Mattar et al., 2013; Mattar et al., 2014). Concentrations of total $P$ and citric acid-soluble $P$ in calcinated bones make it compatible to be used as phosphate fertilizers according to the Brazilian fertilizer legislation (Brasil, 2007).

The bone meal presents substantial phosphate contents, but with low solubility (Ferreira, 2014). There are reports indicating the efficiency and economic viability of using bone meal as phosphorus $(\mathrm{P})$ source for forage sugarcane (Caione et al., 2011), tomatoes (Cavallaro Júnior et al., 2009) and orchids (Rodrigues et al., 2010) production. The use of calcined bone meal in pastures can reduce the use of sources of industrialized phosphates and the pressure on $P$ reserves, estimated to run out in about 150 years (Schroder et al., 2011). Therefore, it is necessary looking for alternative $\mathrm{P}$ sources that minimize the use of industrialized fertilizers, in addition to management practices that result in greater efficiency in the use of the forage resource in order to reduce the pressure on non-deforested areas in the Amazon (Freitas et al., 2005, Noronha et al., 2010).

Management systems that promote minor changes to reduce environmental degradation are indicated (Rodrigues et al., 2017). Thus, for farmers in Rondônia, it has been proposed to adopt agroforestry systems as sustainable agricultural models, also aiming to preserve the forest (Couto et al., 2016). Some family farmers have used calcined bone meal to fertilize forages and vegetables aiming to reduce production costs. However, there is still some doubts regarding the real efficiency of calcinated bone meal efficiency as a P source in the Amazonian cultivated pas- tures. Then, the objective of this study was to evaluate the agronomic performance of irrigated Mombasa grass when fertilized with calcinated bone meal as phosphate fertilizer.

\section{Material and methods}

\section{Characterization of the experimental area}

The experiment was carried out at the experimental farm of the Federal University of Rondônia $\left(11^{\circ} 35^{\prime} 0^{\prime \prime} S 61^{\circ} 46^{\prime} 16 " \mathrm{~W}\right)$, from November 2012 to September 2013, with the following geographical coordinates: longitude, with an altitude of $240 \mathrm{~m}$. The climate of the region is Aw according to the KöppenGeiger classification (Pell et al., 2007), equatorial with variation for hot and humid tropical, with a well-defined dry season (June/September), mean minimum temperature of $24^{\circ} \mathrm{C}$, mean maximum temperature of $32{ }^{\circ} \mathrm{C}$, and average temperature of $28^{\circ} \mathrm{C}$; mean annual rainfall of $2,250 \mathrm{~mm}^{-1}$ year-1; and high relative humidity, of about $85 \%$. The climatic variables during the experimental period are presented in Figures 1 and 2.

The soil of the field is classified as an Haplustox and presented the following attributes at 0-0.2 m depth prior the experiment installation: $\mathrm{pH}$ (in water) $=4.9$; Organic Matter $=21 \mathrm{~g} \mathrm{dm}^{-3}$; $P_{\text {Mehilich }}=2.2 \mathrm{mg} \mathrm{dm}^{-3}$; $K_{\text {Mehilich }}=0.15 \mathrm{cmol}_{\mathrm{c}} \mathrm{dm}^{-3} ; \mathrm{Ca}=0.32 \mathrm{cmol}_{\mathrm{c}} \mathrm{dm}^{-3}$; $\mathrm{Mg}=0.16 \mathrm{cmol}_{\mathrm{c}} \mathrm{dm}^{-3} ; \mathrm{Al}=0.44 \mathrm{cmol}_{\mathrm{c}} \mathrm{dm}^{-3} ; \mathrm{H}+\mathrm{Al}=$ $=5.5 \mathrm{cmol}_{\mathrm{c}} \mathrm{dm}^{-3} ; \mathrm{CEC}_{\mathrm{pH} 7}=6.1 \mathrm{cmol}_{\mathrm{c}} \mathrm{dm}^{-3}$; Sum of Bases $(\mathrm{SB})=0.6 \mathrm{cmol}_{\mathrm{c}} \mathrm{dm}^{-3}$; Base Saturation $(\mathrm{V})=$ $10 \%$; Sand $=322 \mathrm{~g} \mathrm{~kg}^{-1}$; Silt $=89 \mathrm{~g} \mathrm{~kg}^{-1}$; Clay $=$ $=589 \mathrm{~g} \mathrm{~kg}^{-1}$.

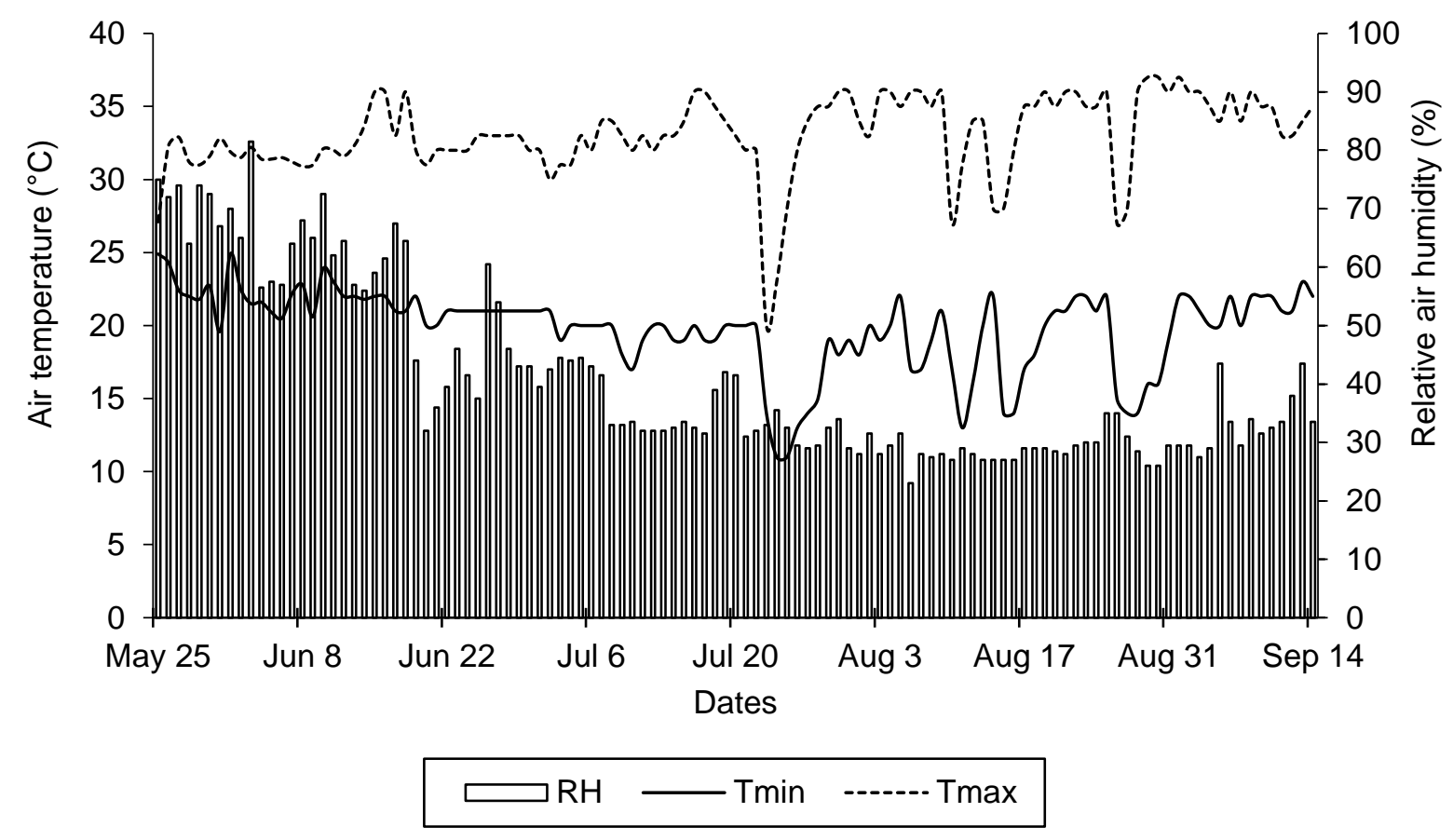

Figure 1 - Maximum temperature (Tmax) and minimum temperature (Tmin) and relative air humidity (RH) from in the experimental field May to September 2013. 


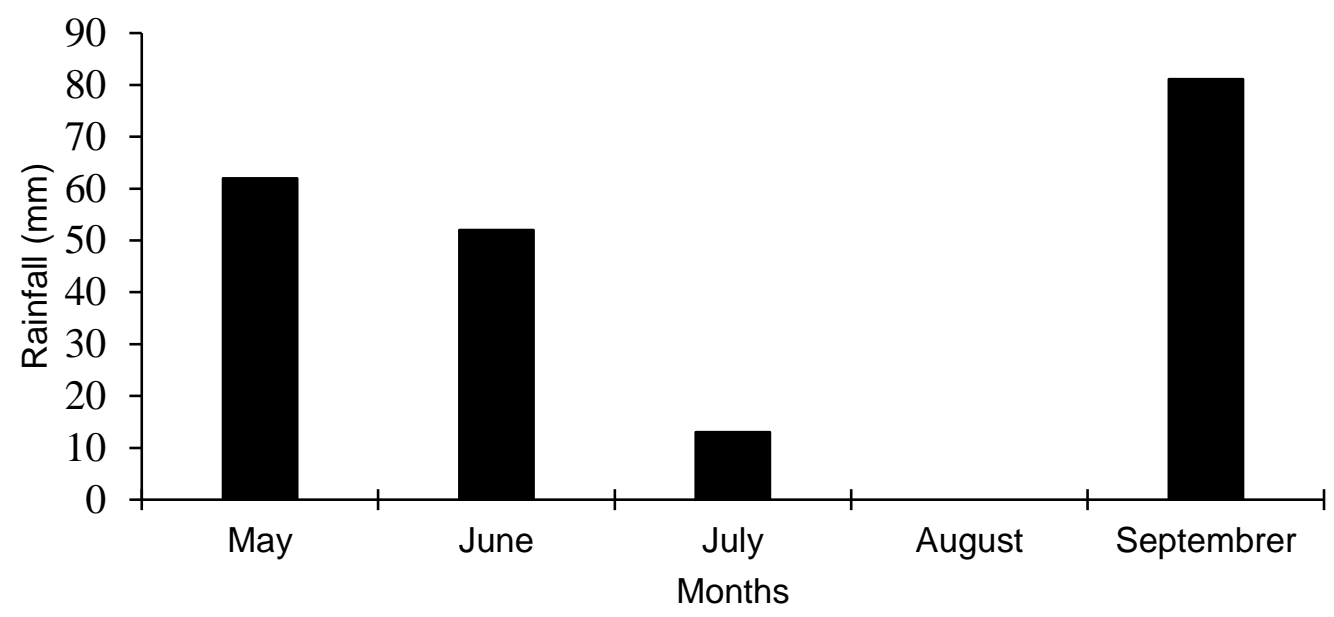

Figure 2 - Rainfall in the experimental field from May to September 2013.

\section{Field experiment installation and management}

Soil preparation consisted in one subsoiling and two disc-harrowings. The first harrowing was performed after the application of dolomitic limestone (80\% TNRP) on $12 / 31 / 2012$, to obtain a base saturation of $60 \%$, and the last one was performed prior to the sowing of Mombasa grass (Panicum maximum $\mathrm{cv}$ Mombasa), on $02 / 23 / 2013$. For seeding were used $30 \mathrm{~kg} \mathrm{ha}^{-1}$ of seeds with cultural value 30 . Potassium chloride $\left(60 \mathrm{~kg} \mathrm{ha}^{-1} \mathrm{~K}_{2} \mathrm{O}\right)$ was broadcast 20 days after sowing and urea (120 kg ha-1 $\mathrm{N})$, was broadcast after each cutting, according Costa (2006).

Irrigation was carried out in the dry season, between May and September 2013, in a conventional sprinkler system, with three sprinklers (Aperjato ${ }^{\circledR}$ model Junior) spaced $13 \mathrm{~m}$ apart applying. Every two days a water depth corresponding to $100 \%$ of the potential evapotranspiration (Equation 1), were applied in a rate of $1.6 \mathrm{~mm} \mathrm{~h}^{-1}$.

$\mathrm{ET}_{\mathrm{pc}}=\mathrm{ET}_{\mathrm{o}} \times \mathrm{Kc}$

Wherein: $E T_{p c}$ is the potential crop evapotranspiration $\left(\mathrm{mm}\right.$ day $\left.^{-1}\right) ; \mathrm{ET}_{\mathrm{o}}$ is the reference evapotranspiration ( $\mathrm{mm}$ day $\left.^{-1}\right)$; and $\mathrm{Kc}$ is the crop coefficient as a function of days after cutting described by Delgado-Rojas et al. (2004) for Panicum maximum cv. Tanzania.

The reference evapotranspiration ( $E T_{0}$ ) was estimated by the method of Hargreaves \& Samani (Samani, 2000) as in Equation 2:

$\mathrm{ET}_{0}=0.0135 \times \mathrm{K} \times \mathrm{Ra} \times \sqrt{(\text { Tmax }-\mathrm{Tmin}) \times(\text { Tmean+17.8) }}$

Wherein: $E T_{0}$ is the reference evapotranspiration $\left(\mathrm{mm}\right.$ day $\left.^{-1}\right) ; \mathrm{K}$ is a coefficient equal to 0.162 for continental regions and 0.190 for coastal regions; $R a$ is the solar radiation at the top of the atmosphere, tabulated for each month and latitude; and Tmax, Tmin and Tmean are the maximum, minimum, and mean air temperatures $\left({ }^{\circ} \mathrm{C}\right)$, respectively.

The gross irrigation depth was determined by the Equation 3:
$\mathrm{GD}=\left(\mathrm{ET}_{\mathrm{pc}}-\mathrm{Rainf}\right) / \mathrm{Ae}$

Wherein: GD is the cumulative daily gross depth to be applied ( $\left.\mathrm{mm} \mathrm{day}^{-1}\right)$; $\mathrm{ET}_{\mathrm{pc}}$ is the potential crop evapotranspiration ( $\left.\mathrm{mm} \mathrm{day}^{-1}\right)$; Rainf is the daily rainfall, when observed $(\mathrm{mm})$; and $A e$ is the application efficiency of the irrigation system, which for the conventional sprinkler was $85 \%$.

\section{Experimental design, treatments, data collection, and analyzed variables}

The experimental design was a randomized complete block, in a $2 \times 3+1$ factorial scheme, with three replications. The first factor was the $P$ sources calcined bone meal (CBM) and single superphosphate (SS). The the second factor were the rates 100,200, and $400 \mathrm{~kg} \mathrm{ha}^{-1} \mathrm{P}_{2} \mathrm{O}_{5}$ (total $\mathrm{P}$ ). A control plot without $\mathrm{P}$ fertilization was included. Bone meal was finely ground (2.00 mm, 9 mesh sieve) and had 34.3\% Ca, 36.3\% total $\mathrm{P}_{2} \mathrm{O}_{5}$ and $0.26 \%$ water-soluble $\mathrm{P}_{2} \mathrm{O}_{5}$. The single superphosphate had $17 \% \mathrm{Ca}, 12 \%$ de S, $21 \%$ total $\mathrm{P}_{2} \mathrm{O}_{5}$, and $17 \%$ water-soluble $\mathrm{P}_{2} \mathrm{O}_{5}$.

The treatments were applied 20 days after sowing (DAS). Forage cutting began 90 DAS, on $05 / 25 / 2013$, at a height of $0.3 \mathrm{~m}$ from the ground. The cuttings for evaluation were carried out every 28 days (at 90, 118, 146, 174, and 202 DAS). Forage dry mass (DM), forage canopy height (FCH), and accumulated dry mass were evaluated. The plot area was $9 \mathrm{~m}^{2}$ $(3 \times 3 \mathrm{~m})$, and the data collection area corresponded to $0.16 \mathrm{~m}^{2}(0.4 \times 0.4 \mathrm{~m})$. The plants were weighed to obtain the fresh mass (FM), and then taken to an oven with forced ventilation at $105^{\circ} \mathrm{C}$ for 72 hours, to obtain the DM. Forage canopy height was measured at three points, considering the top line of the grass canopy.

The accumulated dry mass was obtained by adding the values obtained in the five cuttings during the experimental period. Once the samples were collected, the grass of the entire plots was cut with motorized brush cutter. The cut material was removed, nitrogen was broadcast, and the field was irrigated 
overnight.

The data were submitted to analysis of variance. Qualitative treatments were compared by Tukey's HSD test. For quantitative treatments regression analysis was performed. For statistical procedures were used the free statistical program Assistat (Silva \& Azevedo, 2009).

\section{Results}

There was interaction between rates and sources of applied phosphate $(p<0.01)$ for plant dry mass at 90 , $118,146,174$, and 202 DAS. The DM was higher in the $5^{\text {th }}$ cutting (Figure 3 ), both for treatments with CBM and for SS.

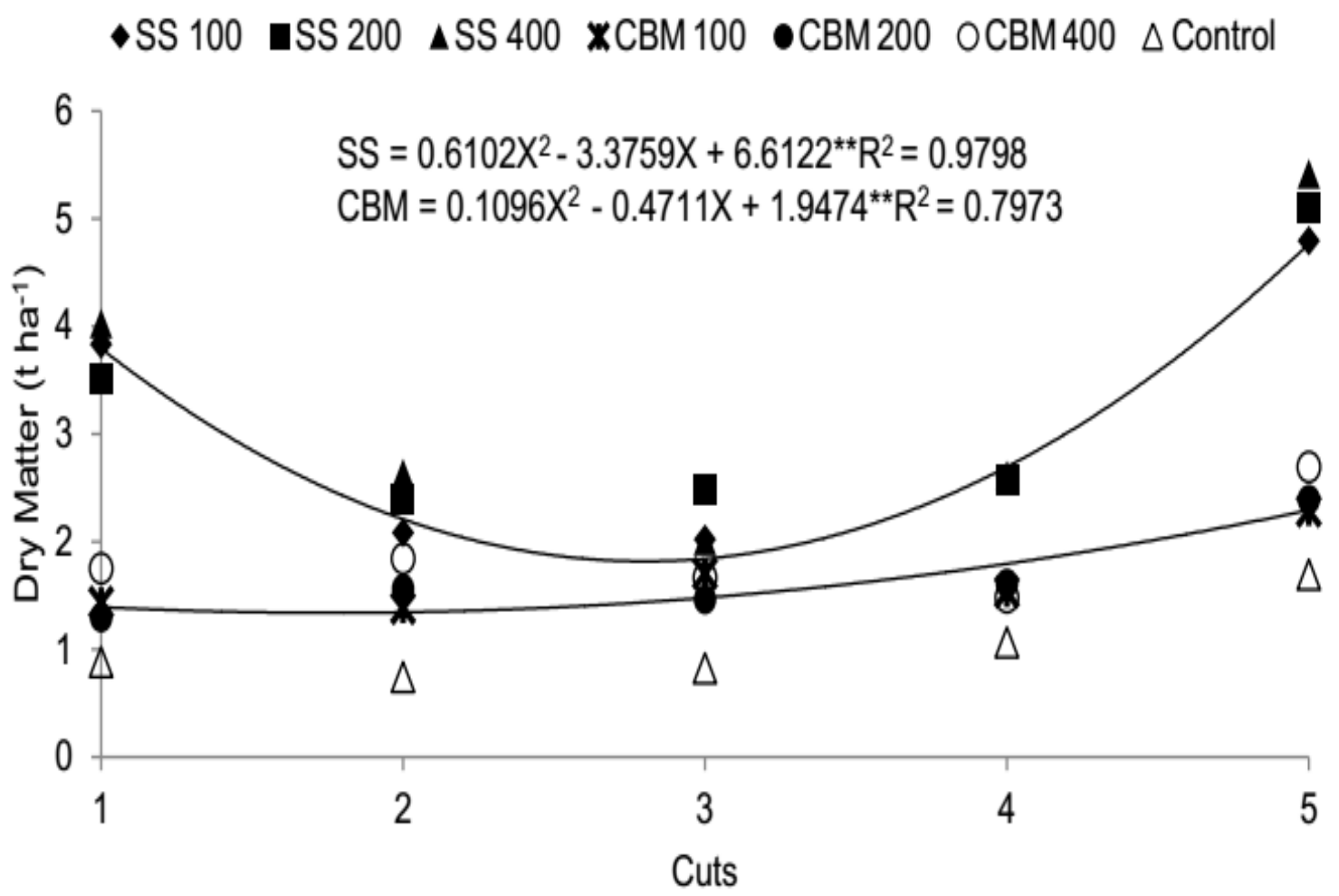

Figure 3 - Dry mass (DM) production of Mombasa grass as affected by sources (calcined bone meal - CBM and single superphosphate - SS) and rates $\left(100,200\right.$ and $400 \mathrm{~kg} \mathrm{ha}^{-1}$ of $\left.\mathrm{P}_{2} \mathrm{O}_{5}\right)$ of phosphorus, in five evaluation cuts. ${ }^{* *}$ Significant by the $\mathrm{F}$ test at $1 \%$ probability $(\mathrm{p}<0.01)$.

Although phosphate fertilization positively influenced yield $(p<0.01)$, the difference in DM production between sources was $2.6 \mathrm{t} \mathrm{ha}^{-1}$. The minimum DM production for both $\mathrm{P}$ sources occurred between the $2^{\text {nd }}$ and $3^{\text {rd }}$ cuttings. In the first cutting, when using SS the dry mass production was higher than in the three subsequent cuttings (Figure 3 ). For the yield behavior, in the fourth and fifth cuttings (174 and 202 DAS), there was an increase in yield (Figure 3), related to the end of the seasonality period for the region.

For both $\mathrm{P}$ sources, there was a significant increase (Figure 4) in the accumulated DM yield when $P$ was added to the soil, showing the importance of this nutrient to the production of the Mombasa grass. When calcined bone meal was used, there was a linear increase $(p<0.01)$ for the accumulated DM yield as a function of the increase in $\mathrm{P}$ rates (Figure 4). For CBM, the highest yield was obtained when $400 \mathrm{~kg} \mathrm{ha}^{-1} \mathrm{P}_{2} \mathrm{O}_{5}$ was used, producing $9.4 \mathrm{tha}^{-1} \mathrm{DM}$, an increase of $81 \%$ in relation to the control plot.

Forage canopy height $(\mathrm{FCH})$ was increased with the $P$ rates, for both $P$ sources (Figure 5). The highest forage canopy height was obtained when SS was used. This level was equivalent to the application of $283 \mathrm{~kg} \mathrm{P}_{2} \mathrm{O}_{5} \mathrm{ha}^{-1}$, similar to that related to the maximum accumulated DM yield $\left(278 \mathrm{~kg} \mathrm{P}_{2} \mathrm{O}_{5} \mathrm{ha}^{-1}\right)$. The correlation between accumulated DM and forage canopy height was $99.96 \%(p<0.01)$. DM production is directly linked to $\mathrm{FCH}$, the higher the forage canopy heights, the larger the DM content. 


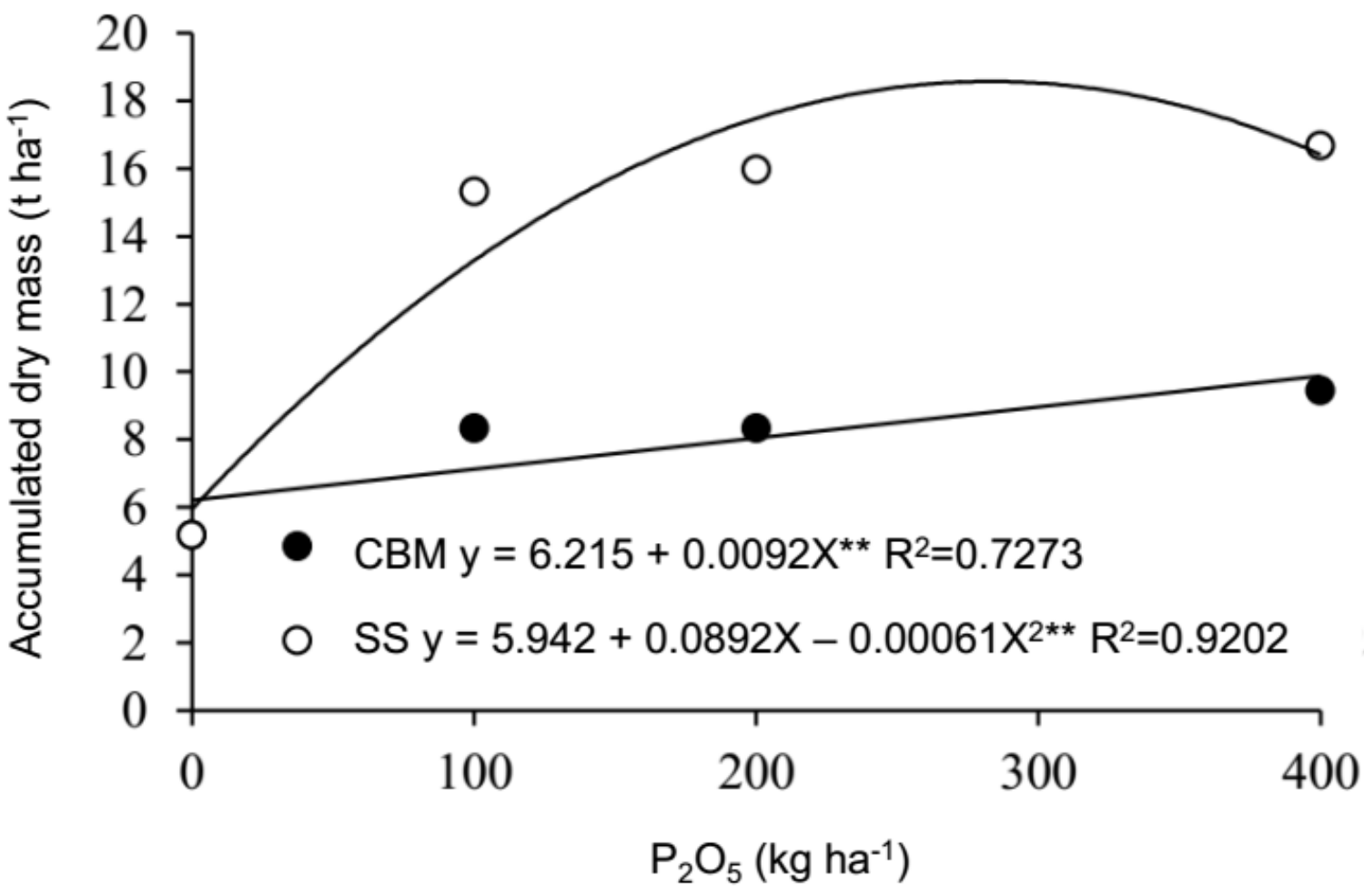

Figure 4 - Accumulated dry mass production of Mombasa grass as affected by sources (calcined bone meal - CBM, and single superphosphate - SS) and rates $\left(100,200\right.$ and $400 \mathrm{~kg} \mathrm{ha}^{-1}$ of $\left.\mathrm{P}_{2} \mathrm{O}_{5}\right)$ of phosphorus. ** Significant by $\mathrm{F}$ test at $1 \%$ probability $(\mathrm{p}<0.01)$.

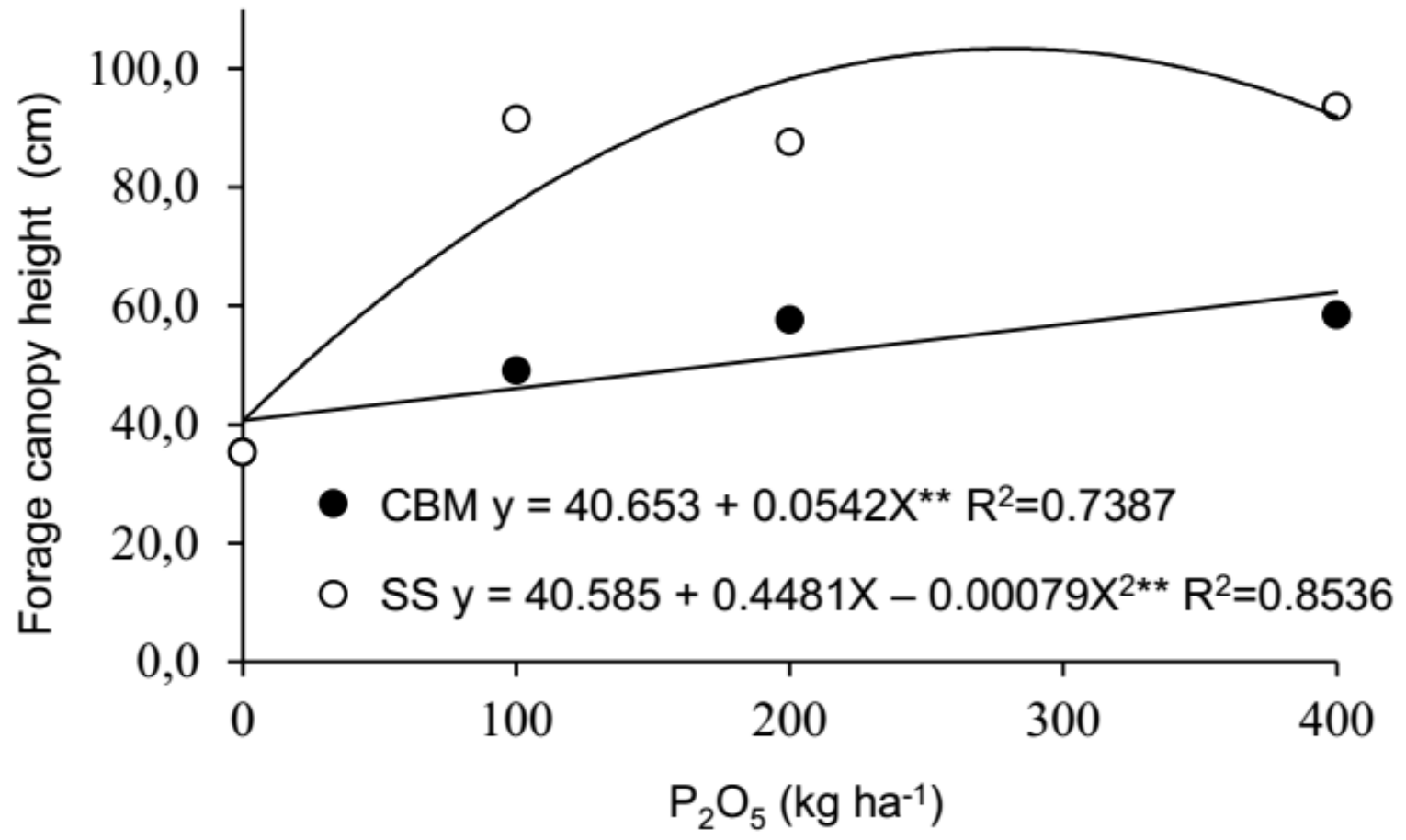

Figure 5 - Forage canopy height $(\mathrm{FCH})$ of Mombasa grass as affected by sources (calcined bone meal - CBM and single superphosphate - SS) and rates (100, 200 and $400 \mathrm{~kg} \mathrm{ha}^{-1}$ of $\left.\mathrm{P}_{2} \mathrm{O}_{5}\right)$ of phosphorus. ${ }^{* *}$ Significant by the $\mathrm{F}$ test at the $1 \%$ probability level $(\mathrm{p}<0.01)$. 


\section{Discussion}

\section{Dry mass of Mombasa as a function of cuttings}

In the seasonal behavior, climatic variables decisively influenced forage yield. This seasonal decline can occur in a period of 65 to 70 days, even though the water needs of the plant are satisfied (Rassini, 2004; Alencar et al., 2009). Other factors such as nutrient availability, soil aeration, the plant's genetic potential, solar radiation, and temperature are cited (Alencar et al., 2009). Under such conditions, irrigation is not able to fully equate the problem of seasonality of production, as in places with higher latitude and altitude, where larger reductions in temperature during winter took place (Alencar et al., 2009; Pariz et al., 2011).

For the region where this study was carried out, it has been observed that the high temperatures (between 30 and $35^{\circ} \mathrm{C}$ ) compromise the dry mass production due to the increase of the vapor pressure difference between the intercellular spaces and the leaf surface (leaf-to-air vapor pressure deficit) and, consequently, may lead to reduced stomatal conductance (Raven et al., 2007). Moreover, the low levels of relative humidity $(\mathrm{RH})$ can compromise the rate of gas exchange, which, in turn, is proportional to the leaf-toair vapor pressure deficit. Even under irrigated conditions, if relative air humidity is low, especially in the hottest hours of the day, plants can reduce stomatal conductance in order to decrease their loss of water to the atmosphere and prevent their dehydration. This reduce the primary net productivity, since the gradient between the soil and the roots and the maximum root conductivity are much smaller than the maximum gradient and conductivity between the leaf and the atmosphere (Pimentel et al., 2004). Along evaluation period (114 days; from the $1^{\text {st }}$ to $5^{\text {th }}$ cutting), $80 \%$ of the time, $\mathrm{RH}$ levels were below $60 \%$, reaching $23 \%$ some days. Furthermore, the reproductive cycle of forages begins in the dry season, interrupting plant growth, due to other physiological reasons (Rassini, 2004).

In the first cutting (90 DAS), it was observed a higher production in relation to the others (Figure 3 ) due to the longer interval, the better conditions at the end of the rain season and the leaf and stem elongation of Mombasa grass when the cutting intervals are longer than 28 to 42 days (Costa, 2004). This longer interval until first cutting / grazing is a pasture management practice used to ensure forage tillering.

The lower rate of leaf and stem elongation in the following cuttings, reducing the DM production of Mombasa, may even become null since the grass has already bloomed (Santos et al., 2004). In this dynamics, the different effects observed with the use of CBM $\left(y=0.110 X^{2}-0.471 X+1.947\right.$ and $\left.R^{2}=0.80\right)$ in relation to SS $\left(y=0.610 X^{2}-3.376 X+6.612\right.$ and $\left.R^{2}=0.98\right)$ can be explained by the higher SS solubility, which initially allowed higher grass yield, but with a lower leaf/stem ratio, which, with the first cutting (30 $\mathrm{cm})$, resulted in a significant reduction of the active photosynthetic area, resulting in DM productions closer to that observed with the use of CBM for the subsequent cuttings (CBM - cuttings 2 and 3 ; Figure 3 ).

\section{Accumulated dry mass}

CBM is a potential P source, however its use alone must undergo acid treatment, to improve its solubility, and even be amended with $\mathrm{S}$, to compete with SS, since a involved in the differences in forage production in short term is the higher solubility and $\mathrm{S}$ content in the industrial source.

In the results obtained with the use of SS, the maximum DM accumulated production was estimated for a rate of $278 \mathrm{~kg} \mathrm{ha}^{-1} \mathrm{P}_{2} \mathrm{O}_{5}$ as being $18.4 \mathrm{t} \mathrm{ha}^{-1} \mathrm{DM}$. This represents an increase of $283 \%$ compared to control plot. This accumulated DM production threshold for the period is similar to that observed by Costa et al. (2004), in the state of Rondônia, that obtained the best productions of Panicum maximum cv Tobiatã when applying $258 \mathrm{~kg} \mathrm{ha}^{-1} \mathrm{P}_{2} \mathrm{O}_{5}$.

Considering the DM yield potential of Mombasa in $21 \mathrm{t} \mathrm{ha}^{-1}$ year-1 (Alencar et al., 2009), the average DM accumulation of the $P$ rates was $41 \%$ of the yield potential for CBM and $76 \%$ for SS.

In relation to the accumulated yield, CBM has reached $54 \%$ of the production obtained with the use of SS. This emphasize the use potential of CBM as a low solubility $P$ source to provide $P$ over time as its dissolved by soil acidity, especially in the Amazonian soils, rich in iron and aluminum oxides/hydroxides that irreversibly adsorbs high-soluble P. Moreover, the potential use of CBM is also evidenced by these results $(54 \%$ of production in relation to SS), since there was no treatment of this source aiming to increase its solubility. The use of hydrochloric acid $(0.5 \%)$ or even citric acid (30\%) can solubilize this source by $42.7 \%$ and $100 \%$, respectively (Duarte et al., 2003). The development of this technology would allow the economy of use of industrial sources, the reduction in the use of machines for the management of phosphate fertilizers, and even the recycling of this nutrient in pasture agroecosystems.

\section{Forage canopy height}

The lower heights observed with the use of CBM are certainly related to the low solubility in water of this $\mathrm{P}$ source $\left(0.26 \% \mathrm{P}_{2} \mathrm{O}_{5}\right.$ soluble), and to the absence of $\mathrm{S}$. At the end of the experimental period the the plots fertilized with CBM presented a green color with lower intensity compared to those treated with SS, suggesting an inadequate $S$ nutrition. Notwithstanding, other visible symptoms of sulfur deficiency were not observed, such as: small leaves, generalized chlorosis, leaf whitening, plant height reduction, necrosis and defoliation, short internodes, reduction of flowering, among others (Avalhares et al. 2009; Ferreira, 2012). It reinforces the importance of including $S$ analysis in the routine reports to evaluate the fertility of the soils of the region when sources such ammonium sulfate, SS or 
phosphogypsum are not adopted in the management of fertility.

The general recommendation for $\mathrm{P}$ fertilization in forage formation is applying high-solubility $\mathrm{P}$ sources in the the planting row, to promote forage establishment. The source of lower solubility must be applied in the total area so that, with its temporal solubilization, it can provide $\mathrm{P}$ to the plants and promote the forage over the years of pasturing. Although CBM has a potential use in pasture fertilization by enabling the supply of $P$ to the forage in a longer period, its treatment in acidic environment can make $P$ available while changing its dynamics in the soil-plant system. This treatment can take place with the prior use of organic or inorganic acids and generate different levels of solubility for this source as a function of their combination, concentration, and time of application (Ferreira et al., 2014).

For the rational exploitation of agroecosystems, the study of bacteria and fungi capable of solubilizing phosphates comes to fill another gap for nutrient cycling, based on phosphate. Microorganisms isolated from Amazonian soils present this capacity due to the production of 2-ketogluconic acid, for example (Chagas Júnior et al., 2010; Souchie et al., 2010). The particularities of Amazonian soils indicate that the adoption of agroforestry systems in the context of family farming can promote the maintenance of soil fertility (Menezes et al., 2008; Silva et al., 2011). Therefore, the development of technologies that rationally use calcined bone meal stands as an important nutrient cycling pathway for the pasture system, mainly when considering that commercial phosphate reserves are a non-renewable resource.

\section{Conclusions}

Using calcined bone meal as a phosphate source for irrigated Mombasa leads to about a half (54\%) of the dry mass production obtained when single superphosphate is used.

Forage yield was certainly influenced by the differences of solubility and nutrient content between the phosphate sources.

\section{References}

Alencar CAB, Oliveira RA, Cóser AC, Martins CE, Cunha FF, Figeuredo JLA (2009) Produção de capins cultivados sob pastejo em diferentes lâminas de irrigação e estações anuais. Revista Brasileira de Engenharia Agrícola e Ambiental 13(6):680-686.

Almeida MIGS, Segundo MA, Lima JLFC, Rangel AOSS (2005) Multi-syringe flow injection system for the determination of available phosphorus in soil samples. International Journal of Environmental Analytical Chemistry 85(1):51-62.
Avalhares CC, Prado RM, Rozane DE, Romualdo LM, Correia MAR (2009) Omissão de macronutrientes no crescimento e no estado nutricional de capim elefante (cv Mott) cultivado em solução nutritiva. Scientia Agraria 10(3):215-212.

Brasil - Instrução Normativa 5/2007 do Ministério da Agricultura, Pecuária e Abastecimento (2007) Aprova as definições e normas sobre as especificações e as garantias, as tolerâncias, o registro, a embalagem e a rotulagem dos fertilizantes minerais destinados à agricultura. Disponível em <http://sistemasweb.agricultura.gov.br/sislegis/action/d etalhaAto.do?method=recuperarTextoAtoTematicaPort al\&codigoTematica $=1229260>$. Accesso em 16 nov. 2017

Caione G, Lange A, Benett CGS, Fernandes FM (2011) Fontes de fósforo para adubação de cana-deaçúcar forrageira no cerrado. Pesquisa Agropecuária Tropical https://dx.doi.org/10.5216/pat.v41i1.8497.

Cavallaro Júnior ML, Trani PE, Passos FA, Kuhn Neto J, Tivelli SW (2009) Produtividade de rúcula e tomate em função da adubação $\mathrm{N}$ e $\mathrm{P}$ orgânica e mineral. Bragantia 68(2):347-356 https://dx.doi.org/10.1590/S0006-87052009000200008

Chagas Junior AF, Oliveira LA, Oliveira A, Willerding AL (2010) Capacidade de solubilização de fosfatos e eficiência simbiótica de rizóbios isolados de solos da Amazônia. Acta Scientiarum. Agronomy 32(2):359366. ttps://dx.doi.org/10.4025/actasciagron.v32i2.3185.

Costa NL (2004) Formação, manejo e recuperação de pastagens em Rondônia. Porto Velho. Embrapa Rondônia, 219p.

Costa NL (2006) Adubação Fosfatada na Recuperação de Pastagens Degradadas de Brachiaria brizantha cv. Marandu. Embrapa Amapá. Disponível http://www.agrosoft.org.br/agropag/19428.htm. Acessado em: 07 fev.2014.

Couto WH, Anjos LHC, Wadt PGS, Pereira MG (2016) Atributos edáficos e resistência a penetração em áreas de sistemas agroflorestais no sudoeste amazônico. Ciência Florestal 26(3):811-823. https://dx.doi.org/10.5902/1980509824210.

Delgado-Rojas JS, Novaes M, Lourenço LF, Coelho RD (2004) Evapotranspiração máxima do capim "Tanzânia" (Panicum maximum J.) em pastejo rotacionado, baseada na evaporação do tanque "Classe A" e no índice de área foliar. Engenharia Agrícola 24(1):226234. 69162004000100026 
Dias-Filho MB (2015) Estratégias para recuperação de pastagens degradadas na Amazônia brasileira. Embrapa Amazônia Oriental, Documentos 411, 25p.

Duarte HC, Graça DS, Borges FMO, Di Paula OJ (2003) Comparação de métodos "in vitro" para determinação da biodisponibilidade de fósforo. Arquivos Brasileiro de Medicina Veterinária e Zootecnia 55(1):80-84.

Ferreira AVL, Ferreira E, Cavali J, Porto MO, Stachiw R (2014) Farinha de ossos calcinada. Revista Brasileira de Ciências da Amazônia 3(1):29-36.

Ferreira E (2014) Utilização de resíduos na agricultura: Farinha de ossos calcinada. In: II Reunião de Ciência do Solo da Amazônia Ocidental, p. 75-86. Editores: Wadt PGS, Marcolan Al, Matoso SCG, Pereira MG, Manejo dos solos e sustentabilidade agrícola na Amazônia Ocidental. SBCS, Porto Velho, 286p.

Ferreira MMM (2012). Sintomas de deficiência de macro e micronutrientes de planta de milho híbrido BRS1010. Revista Agro@mbiente On-line 6(1):74-83.

Freitas KR, Rosa B, Nascimento JL, Ruggiero JA, Heinemam AB, Ferreira PH, Macedo R (2005) Avaliação do capim mombaça (Panicum maximum Jacq.) submetido a diferentes doses de nitrogênio. Acta Scientiarum http://dx.doi.org/10.4025/actasciagron.v27i1.2154.

leiri AY, Lana RMQ, Korndörfer GH, Pereira HS (2010) Fontes, doses e modos de aplicação de fósforo na recuperação de pastagem com brachiaria. Ciência e Agrotecnologia https://dx.doi.org/10.1590/S1413-

70542010000500011.

Mattar EPL, Frade Junior EF, Oliveira E (2013) Cinza de osso - Fósforo e cálcio para agricultura. Cruzeiro do Sul: UFAC, $25 \mathrm{p}$.

Mattar EPL, Frade Junior EF, Oliveira E (2014) Caracterização de cinza de osso bovino para avaliação de seu potencial uso agrícola. Pesquisa Agropecuária Tropical 11(1):65-70.

Menezes JMT, Leeuwen J, Valeri SV, Cruz MCP, Leandro RC (2008) Comparação entre solos sob uso agroflorestal e em florestas remanescentes adjacentes, no norte de Rondônia. Revista Brasileira de Ciên$\begin{array}{lll}\text { cia do Solo } & \text { 32(2):893-898. }\end{array}$ https://dx.doi.org/10.1590/S0100-06832008000200043.

Miyahara RY, Gouvêa D, Toffoli SM (2007) Obtenção e caracterização de cinza de ossos bovinos visando à fabricação de porcelana de ossos - bone china.

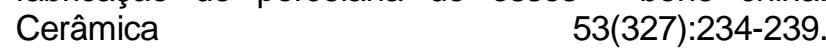
https://dx.doi.org/10.1590/S0366-69132007000300004

Noronha NC, Andrade CA, Limonge FC, Cerri CC, Cerri CEP, Piccolo MC, Fiegl BJ (2010) Recovery of degraded pasture in Rondônia: macronutrients and productivity of Brachiaria brizantha. Revista Brasileira de Ciência Solo 34(5):1711-1720. https://dx.doi.org/10.1590/S0100-06832010000500023
Pariz CM, Andreotti M, Bergamaschine AF, Buzetti S, Costa NR, Cavallini MC, Ulian NA, Luiggi FG (2011) Yield, chemical composition and chlorophyll relative content of Tanzania and Mombaça grasses irrigated and fertilized with nitrogen after corn intercropping. Revista Brasileira de Zootecnia 40(4):728-738. https://dx.doi.org/10.1590/S1516-35982011000400005

Peel MC, Finlayson BL, McMahon TA (2007) Updated world map of the Köppen-Geiger climate classification. Hydrology and Earth System Sciences 11(5):16331644. https://doi.org/10.5194/hess-11-1633-2007.

Pimentel C (2004) A relação da planta com a água. Seropédica: UFRRJ. 191 p.:il.

Rassini JB (2004) Período de estacionalidade de produção de pastagens irrigadas. Pesquisa Agropecuária Brasileira 39(8):821-825 https://dx.doi.org/10.1590/S0100-204X2004000800014

Raven PH, Evert RF, Eichhorn SE (2007) Biologia Vegetal. $7^{\text {a }}$ Edição. Rio de Janeiro: Guanabara Koogan. 830 p.

Rodrigues DT, Novais RF, Alvarez VH, Dias, JMM, Villani EMA (2010) Orchid growth and nutrition in response to mineral and organic fertilizers. Revista Brasileira de Ciência do Solo 34(5):1609-1616. https://dx.doi.org/10.1590/S0100-

06832010000500014.

Rodrigues M, Rabêlo FHS, Castro HA, Roboredo D, Carvalho MAC, Roque CG (2017) Changes in chemical properties by use and management of an oxisol in the Amazon biome. Revista Caatinga 30(2):278-286. https://dx.doi.org/10.1590/1983-21252017v30n202rc.

Samani Z (2000) Estimating solar radiation and evapotranspiration using minimum climatological data. Journal of Irrigation and Drainage Engineering 126(4):265-267.

Santos PM, Balsalobre MAA, Corsi M (2004) Características morfogenéticas e taxa de acúmulo de forragem do capim-Mombaça submetido a três intervalos de pastejo. Revista Brasileira de Zootecnia 33(4):843-851 Available from http://www.scielo.br/scielo.php?script=sci_arttext\&pid= S1516-35982004000400004\&lng=en\&nrm=iso.

Schroder JJ, Smit AL, Cordell D, Rosemarin A (2011) Improved phosphorus use efficiency in agriculture: $A$ key requirement for its sustainable use. Chemosphere 84(6):822-831.

https://dx.doi.org/10.1016/j.chemosphere.2011.01.065.

Silva FAS, Azevedo CAV (2009) Principal components analysis in the software Assistat - Statistical Attendance In: World Congress on Computers in Agriculture 7 Reno NV USA. American Society of Agricultural and Biological Engeneers. Disponível em http://www.assistat.com/indexp.html 
Silva DC, Silva MLN, Curi N, Oliveira AH, Souza FS, Martins SG, Macedo RLG (2011) Atributos do solo em sistemas agroflorestais, cultivo convencional e floresta nativa. Revista de Estudos Ambientais 13(1):77-86. http://dx.doi.org/10.7867/1983-1501.2011v13n1p77-86.

Souchie EL, Azcón R, Barea JM, Silva EMR, SagginJúnior OJ (2010) Enhancement of clover growth by inoculation of P-solubilizing fungi and arbuscular mycorrhizal fungi. Anais da Academia Brasileira de Ciências 82(3):771-777 https://dx.doi.org/10.1590/S0001-37652010000300023.
Teixeira PEG, Fernandes AR, Galvão JR, Pereira WVS, Casanova SRA, Filho PPCA (2016) Cowpea yield on soils with residues of NPK and natural phosphate fertilizers in succession the area of degraded pasture. Revista Ceres 63(4):553-567. https://dx.doi.org/10.1590/0034-737X201663040017.

Townsend CR, Costa NL, Pereira RGA (2010) Aspectos econômicos da degradação de pastagens na Amazônia brasileira. Revista Amazônia: Ciência \& Desenvolvimento 5(10):27-49. 